\title{
Profitability Analysis of a Four Crop Based Cropping Pattern in Bogura Region of Bangladesh
}

\author{
Md. Tanbir Hasan, Md. Shahidul Alam, Md. Zulfikar Haider Prodhan, \\ Md. Monowarul Islam Chowdhury, and Md. Aminul Islam
}

\section{ABSTRACT}

\begin{abstract}
Farmers in the Bogura region benefit significantly from the systematic use of crop rotation. The experiment was performed at the Shibganj, Bogura, in 2015-16 and 2016-17 to create a potato-Boro-radish-T. Aman rice crop sequence that would compete with the potato-Boro-T. Aman rice crop sequence. Primary objectives of the experiment were to determine the cost of producing enhanced Potato-Boro-Radish-T. Aman rice and compare it to current potato-boro-t. aman rice. There were two patterns: Current Cropping Pattern Potato (BARI Alu-8)-Boro (BRRI dhan 28)-T. Aman (BRRI dhan-49) and Alternative Cropping Pattern Potato (BARI Alu-25)Boro (BRRI dhan 28) -Radish (Rocky)-T. Aman (BRRI dhan-57). The research revealed that an alternative cropping pattern required average crop duration of $\mathbf{3 1 5}$ days to complete one cycle in a year, implying that a four multiple cropping sequence was economically viable to replace the current cropping pattern. In terms of mean REY, the total grain/tuber yield was $42.80 \mathrm{t} / \mathrm{ha} / \mathrm{year}$, which was $66 \%$ greater than the current pattern $(25.76$ t/ha/year). The overall production efficiency $(185.14 \mathrm{~kg} / \mathrm{ha} / \mathrm{day})$, usage of land $(86.16 \%)$, and engagement in the population (660 man-days/ha/year) of the alternative cropping pattern were 45,7 , and $41 \%$ higher, respectively, than the current cropping pattern. Alternative cropping patterns had the gross benefit of $274911 \mathrm{Tk}$./ha/year, indicating that they were sparingly sustainable. The alternative crop sequence also improved crop strength, growers' real understanding, technique, profits, and engagement. Furthermore, by trying to incorporate $T$. aman straw into soil with an alternative cropping pattern, it promotes soil health. As a result, farmers in Bangladesh's Bogura region may employ a different planting pattern on their variable land in order to boost production and profitability while also creating jobs.
\end{abstract}

Keywords: Crop sequence, Crop rotation, Level of Productivity, Rice comparable yield, Usage of land.
Submitted : October 02, 2021

Published : December 10, 2021

ISSN: 2684-1827

DOI: 10.24018 /ejfood.2021.3.6.387

Md. Tanbir Hasan*

Bangladesh Agricultural Research Institute, OFRD, Bogura-5800, Bangladesh.

(e-mail: tanbirhasanshuvo88@gmail.com) Md. Shahidul Alam

Bangladesh Agricultural Research Institute, OFRD, Bogura-5800,

Bangladesh.

(e-mail: alamsrc84@ yahoo.com)

Md. Zulfikar Haider Prodhan

Bangladesh Agricultural Research

Institute, TCRSC, Bogura-5800,

Bangladesh.

(e-mail: zulfukarhaider@yahoo.com)

Md. Monowarul Islam Chowdhury

Bangladesh Agricultural Research

Institute, OFRD, Shampur, Rajshahi-6205, Bangladesh.

(e-mail: monowaru120@yahoo.com)

Md. Aminul Islam

Bangladesh Agricultural Research

Institute, OFRD, Bogura-5800,

Bangladesh.

(e-mail: amin.agron ${ }^{\circledR}$ gmail.com)

*Corresponding Author

\section{INTRODUCTION}

Bangladesh is the most densely inhabited nation on the planet, through a land area of 1,47,570 square kilometers (approximately 1033 people per square kilometer). It currently has a people of approximately 152.40 million populaces and is rising at a proportion of around $1.37 \%$ per year [1]. By 2030, the populace will be roughly 186 million [2]. The whole cultivable land area in the state is around 8.44 million hectares, and it is depleting on a daily basis. Segment of the population pressures and increased urbanization have resulted in a $1 \%$ annual decrease in cropland. In the next 25 years, the country's food measures are expected to double [3]. Our finite and diminishing land resources must be used to meet the demand. There is little space available for cultivable land expansion, but there are opportunities to increase cropping intensity from $192 \%$ to $192 \%$ by improving existing cropping patterns and trying to incorporate short-duration crops into the paddy cropping system [4].

Bogura drops under Agro Ecological Zones (AEZ) 3, 4, and 27. Non-calcareous gray and brown floodplain soils predominate in the Tista Meander Floodplain. The KaratoyaBangali Floodplain has a variety of soil types, with noncalcareous gray and dark grey floodplain soils predominating. The Deep Red Brown Terrace soils and the Deep Grey Terrace soils make up the majority of the universal soil types found in the North Eastern Barind Tract. Approximately 79\% of the land is classified as high or middle high land, with the potential to produce multiple crops per year. Potato-Boro-T. Aman is a main cropping pattern in Bogura's Shibganj upazilla, which spans approximately 18170 hectares. Shibganj has a cropping intensity of $271.47 \%$ right now [5]. Cropping intensity in this region may be enhanced by utilizing short-duration crop types produced by BARI and other research institutions. Bogura is Bangladesh's largest potato-growing district, and one of the most common patterns of cropping in the area is potato-boro-t. aman [5]. The land is left fallow after Boro rice harvesting. Radish can be easily added after the Boro rice has already been roasted. As a result, the addition of Radish to the potato-boro-t. aman cropping 
techniques is expected to growth crop rotation strength and profitability in the Bogura state. Adopting this alternative cropping style of potato-boro-radish-t. aman dismiss assist rural poor farmers in the region in earning additional income and creating jobs. As a result of the current potato-based cropping pattern, farmers in Bogura face economic losses. As a result, farmers in the Bogura region will need to adopt a more beneficial cropping pattern.

BARI recently created several multiple cropping patterns that will be beneficial to farmers. Potato-Boro-Radish-T. Aman is single of them. This cropping style is desired to validate the current Potato-Boro-T. Aman cropping modes in the fields of Bogura farmers. It is possible to generate extra employment possibilities by growing multiple crops in a year on the same piece of land, as well as food and nutritional security for farmers. Simultaneously, cropping severity and output can be amplified [4], [6]. Furthermore, several reports on cropping patterns indicate that an added crop could be familiarized with minimal variations or substituted for current crops to significantly increase farmers' productivity and profitability [7]-[13]. Cropping intensity must be increased to crop more food on a limited volume of property, and thus more suitable crop(s) should be included in the cropping pattern. The objective of the research was to examine a multiple cropping pattern to a three-crop cropping style.

\section{MATERIALS AND METHODS}

During the cropping cycles of 2015-16 and 2016-17, the trial was conducted in the farmers' fields of the Shibganj, Bogura. Before and after the two cycles of the experiment, soil samples were collected from 0-15 cm depth to establish benchmark and post soil characteristics, respectively. As part of SRDI's soil analysis, separate soil samples were air dried, pulverized, and examined.

The experiment was designed in a block format to ensure that all activities occurred in the correct order. In each of the six farmers' cropping patterns, there were two one-hectare blocks. Potato was the alternative cropping pattern used on one block. Potato (BARI Alu-25)-Boro (BRRI dhan-28)Radish (Rocky)-T. Aman (BRRI dhan-57) was bred against an existing pattern. Potato (BARI Alu-8)-Boro (BRRI dhan 28)-T.Aman (BRRI dhan-49).

The trial began with the cultivation of potatoes in both alternative and current cropping patterns. Rice seedlings were transplanted $20 \times 15 \mathrm{~cm}$ apart, and potato seeds were sown in rows. Following best management practices, entirely fertilizers were treated twice, once as a base and once as a top dressing. Table II summarizes the agricultural factors and intercultural operations for crop development with upgraded and producer methods. Stem borer and sheath blight were found in some Boro and T. Aman rice plots. Folicur was applied at a rate of $0.5 \mathrm{ml} / \mathrm{L}$ to regulator sheath blight, and Virtaklo $40 \mathrm{WG}$ was applied at a rate of $1.5 \mathrm{~g} / 10 \mathrm{~L}$ to control stem borer. To control late blight disease, Acrobat MZ @ $2 \mathrm{~g} / \mathrm{L}$ was sprayed on the potato, and Tido $20 \mathrm{SL}(0.5 \mathrm{ml} / \mathrm{L})$ was covered on the potato to control aphids and jassid. All enhanced and farmer-specific field operations and management techniques were carefully monitored, and data was gathered to assess agro-economic performance. $1 \mathrm{~m}^{2}$ of each block was sampled for data on product and by-product yields.

Cropping patterns' agronomic performance was calculated, including Usage of land, Level of Productivity, and Rice comparable yield.

\section{A. Usage of Land}

It is calculated by dividing the overall period of each crop in an arrangement by 365 days [14] (Tomer and Tiwari, 1990) as follows:

$$
\text { Usage of Land }=\frac{\sum d_{i}}{365} \times 100
$$

where, $d_{i}=$ period of $i^{\text {th }}$ crop;

$i=1,2,3$, and 4 .

\section{B. Level of Productivity}

To calculate level of production in $\mathrm{kg} / \mathrm{ha} /$ day, overall invention in a cropping style was distributed by total period of crops in that pattern [14].

$$
\text { Level of productivity }=\frac{\sum y_{i}}{\sum d_{i}}
$$

where,

$y_{i}=$ Yield of $i^{\text {th }}$ crop;

$d_{i}=$ duration of $i^{\text {th }}$ crop;

$i=1,2,3$ and 4 .

\section{Rice Comparable Yield}

To make a comparison of cropping patterns, the yields of all crops were converted to rice comparable yields using the current market price of the individual crop [15].

Rice comparable Yield $\left(t h a^{-1}\right)=\frac{\text { Yield of each crop } \times \text { Current price of this crop }}{\text { Current price of T.Aman }}$

\section{Analysis of the Profitability}

Economic guides such as total variable cost and gross return were also computed using product market prices. Using regular data from two crop circle, the financial evaluation of two cropping patterns was carried out. The taka value of the product and by-product per hectare was used to calculate the gross return. For different agricultural production processes and inputs, the total flexible rate of various collects was estimated using taka per hectare. To compare the benefits, fractional budgeting was utilized. The advantage was determined by subtracting the entire economic difficulty from the total economic benefit.

\section{RESULTS AND DISCUSSION}

\section{A. Changes in Soil Characteristics}

The results in Table I illustrate and explain post-soil nutrient status. The soil was initially slightly acidic, had a moderate amount of organic matter, and was deficient in potassium, zinc, and boron. S content was moderate. The total 
nitrogen content was extremely low, while the P content was optimal. Soil was also tested following the completion of two-year cycles. The soil's $\mathrm{pH}$ was marginally higher than the opening value, and the organic matter content was slightly lower, according to the post-analysis chemical analysis. P, S, and $\mathrm{N}$ reduced in post soil, but $\mathrm{K}, \mathrm{Zn}$, and $\mathrm{B}$ gained. The results of Mondal et al. [4] are in favor with the outcomes.

\section{B. Crop Management}

Crop management techniques include, among other things, sowing/transplanting date, harvesting date, the amount of fertilizer hand-me-down, irrigation, clearing, and pesticide application. The first and second cycles of the alternative cropping pattern (Potato-Boro-Radish-T. Aman rice) were completed in 317 and 312 days, respectively. Although the current cropping pattern (Potato-Boro-T. Aman rice) completed the first and second cycles in 295 and 293 days, the turnaround time for the first and second cycles of four crop-based alternative cropping patterns was 48 and 53 days, respectively, compared to 70 and 72 days for current cropping patterns. This demonstrates that a multiple-crop alternative pattern, as opposed to the current three-crop pattern, can easily fit on a plot of land in one year.

\section{Grain/Tuber Yield}

The mean grain/tuber yields of Potato, Boro, Radish, and T. Aman in alternative cropping patterns were 26.25, 5.45, 22.59 , and $3.94 \mathrm{t} / \mathrm{ha}$, including both, whereas in current cropping patterns, the imply grain/tuber yields of Potato, Boro, Radish, and T. Aman were 26.80, 5.57, and 5.11 t/ha, respectively (Table III). Table III presents the straw yields of the aforementioned crops. Boro rice produced a high yield, which could be attributed to the use of fertilizer in potato crops. Due to an initial flea beetle attack, the yield of radish in alternative cropping cycle ( $2^{\text {nd }}$ cycle) was low. Grain/tuber yield of Potato, Boro, Radish, and T. Aman were 26.10, 5.44, 24.90 , and $3.70 \mathrm{t} / \mathrm{ha}$, including both, for the first cycle in the alternative cropping pattern, while grain/tuber yield of Potato, Boro, and T. Aman were 26.80, 5.56, and $5.12 \mathrm{t} / \mathrm{ha}$, respectively, in the current pattern. Grain/tuber yield of Potato, Boro, Radish, and T. Aman were 26.40, 5.46, 20.29, and $4.19 \mathrm{t} / \mathrm{ha}$, it's between, in the second cycle of alternative cropping pattern, while in the current pattern grain/tuber yield of Potato, Boro, and T. Aman were 26.81, 5.59, and 5.10 t/ha, in both. Rahman et al. [7] realized similar results.

TABLE I: Four Crop-Based Cropping Pattern Area at MLT Site ShibganJ, Bogura Had Both Initial and Final SoIl Characteristics in 201516 AND 2016-17

\begin{tabular}{|c|c|c|c|c|c|c|c|c|c|}
\hline \multirow[t]{2}{*}{ Soil sample } & \multirow[t]{2}{*}{ Land type } & \multirow{2}{*}{$\mathrm{pH}$} & \multirow{2}{*}{$\begin{array}{c}\text { Organic } \\
\text { matter }(\%)\end{array}$} & \multirow{2}{*}{$\begin{array}{c}\text { Total N } \\
(\%)\end{array}$} & \multirow{2}{*}{$\frac{(\mathrm{meq} / 100 \mathrm{~g})}{\mathrm{K}}$} & \multicolumn{4}{|c|}{$\left(\mu \mathrm{g} \mathrm{g}^{-1}\right)$} \\
\hline & & & & & & $\mathrm{P}$ & $\mathrm{S}$ & $\mathrm{Zn}$ & B \\
\hline Initial & MHL & 6.7 & 1.70 & 0.08 & 0.15 & 16.52 & 18.12 & 0.78 & 0.28 \\
\hline Final & MHL & 6.8 & 1.68 & 0.07 & 0.16 & 15.76 & 17.87 & 0.96 & 0.32 \\
\hline Critical Limit & - & - & - & 0.12 & 0.12 & 7.0 & 10.0 & 0.6 & 0.2 \\
\hline
\end{tabular}

MLT= Multi-Location Testing, MHL= Medium High Land.

TABLE II: Crop Control Techniques of the CurRent (PotAto-Boro-T. Aman) AND Alternative Cultivation Practices (PotAto-BoroRADISH-T. AMAN) CROPPING STYLE IN THE FIRST AND SECOND CYCLES AT SHIBGANJ, BogURA

\begin{tabular}{|c|c|c|c|c|c|c|c|}
\hline \multirow{2}{*}{$\frac{\text { Parameters }}{\text { Crop }}$} & \multicolumn{3}{|c|}{ Current Cropping Pattern } & \multicolumn{4}{|c|}{ Alternative Cropping Pattern } \\
\hline & Boro & T. Aman & Potato & Boro & Radish & T. Aman & Potato \\
\hline Variety & $\begin{array}{l}\text { BRRI dhan - } \\
28\end{array}$ & BRRI dhan-49 & BARI Alu-8 & $\begin{array}{l}\text { BRRI dhan - } \\
28\end{array}$ & Rocky & $\begin{array}{l}\text { BRRI dhan- } \\
57\end{array}$ & BARI Alu-25 \\
\hline \multicolumn{8}{|l|}{$1^{\text {st }}$ cycle } \\
\hline $\begin{array}{l}\text { Fertilizer dose (CD t/ha, } \\
\text { NPKSZnBMg Kg/ha) }\end{array}$ & $\begin{array}{l}0,104-18-37- \\
14-0-0-0\end{array}$ & $\begin{array}{c}0,108-22-37-13- \\
0-0-0\end{array}$ & $\begin{array}{l}0,120-50-110- \\
22-3-2-0\end{array}$ & $\begin{array}{l}5,120-18-75- \\
18-5-2-0\end{array}$ & $\begin{array}{c}0,160-40 \\
-82-15-0-0-0\end{array}$ & $\begin{array}{l}0,70-11-25- \\
10-2-0-0\end{array}$ & $\begin{array}{c}0,110-30- \\
100-16-3-2- \\
10\end{array}$ \\
\hline $\begin{array}{c}\text { Transplanting/ seeding } \\
\text { date }\end{array}$ & 01-03 Feb. 16 & 13-15 July, 16 & 06-08 Nov. 16 & 1-2 Feb.16 & 3-5 June, 16 & 30-31July, 16 & $\begin{array}{c}\text { 01-03 Nov. } \\
16\end{array}$ \\
\hline Harvesting time & 17-19 May, 16 & $28-30$ Oct. 16 & 26-28 Jan, 17 & 17-18 May, 16 & 22-25 july, 16 & 17-20 Oct. 16 & 20-22 Jan. 17 \\
\hline Intercultural Operation & $\begin{array}{l}\text { Irrigation } 15 \\
\text { times \& } \\
\text { weeding } 2 \\
\text { times }\end{array}$ & $\begin{array}{l}\text { Weeding } 3 \\
\text { times }\end{array}$ & $\begin{array}{l}\text { Irrigation } 2 \\
\text { times \& } \\
\text { weeding } 2 \\
\text { times }\end{array}$ & $\begin{array}{l}\text { Irrigation } 15 \\
\text { times \& } \\
\text { weeding } 2 \\
\text { times }\end{array}$ & $\begin{array}{l}\text { Irrigation } 2 \\
\text { times \& } \\
\text { weeding } 2 \\
\text { times }\end{array}$ & $\begin{array}{l}\text { Weeding } 3 \\
\text { times }\end{array}$ & $\begin{array}{l}\text { Irrigation } 2 \\
\text { times \& } \\
\text { weeding } 2 \\
\text { times }\end{array}$ \\
\hline Longevity (days) & 105 & 110 & 80 & 105 & 50 & 82 & 80 \\
\hline $\begin{array}{l}\text { Turnaround period } \\
\text { (days) }\end{array}$ & 6 & 59 & 5 & 13 & 15 & 6 & 14 \\
\hline $\begin{array}{c}\text { Fertilizer dose (CD tha- }{ }^{1} \text {, } \\
\text { NPKSZnBMg } \\
\left.\text { kgha- }^{-1}\right)\end{array}$ & $\begin{array}{l}5,140-20-50- \\
9-2.5-0-0\end{array}$ & $\begin{array}{c}0,70-19-35-10- \\
0-0-0\end{array}$ & $\begin{array}{l}0,170-25-130- \\
15-2-1-10\end{array}$ & $\begin{array}{l}5,130-18-53- \\
9-2.7-1-0\end{array}$ & $\begin{array}{c}0,172-45 \\
-112-17-0-0- \\
0\end{array}$ & $\begin{array}{l}0,76-12-26- \\
8.4-0-0-0\end{array}$ & $\begin{array}{c}0,161-24- \\
125-16-3-1.3- \\
10\end{array}$ \\
\hline $\begin{array}{c}\text { Transplanting/ seeding } \\
\text { date }\end{array}$ & 01 Feb. 17 & 12 July, 17 & 08 Nov. 17 & 01 Feb.17 & 03 June, 17 & 30 July, 17 & 03 Nov. 17 \\
\hline Harvesting time & 16 May, 17 & 30 Oct.17 & 27 Jan, 17 & 15 May, 17 & 23 July, 17 & 19 Oct. 17 & 22 Jan...18 \\
\hline Intercultural Operation & $\begin{array}{l}\text { Irrigation } 15 \\
\text { times \& } \\
\text { weeding } 2 \\
\text { times }\end{array}$ & $\begin{array}{l}\text { Weeding } 3 \\
\text { times }\end{array}$ & $\begin{array}{l}\text { Irrigation } 2 \\
\text { times \& } \\
\text { weeding } 2 \\
\text { times }\end{array}$ & $\begin{array}{l}\text { Irrigation } 15 \\
\text { times \& } \\
\text { weeding } 2 \\
\text { times }\end{array}$ & $\begin{array}{l}\text { Irrigation } 2 \\
\text { times \& } \\
\text { weeding } 2 \\
\text { times }\end{array}$ & $\begin{array}{l}\text { Weeding } 3 \\
\text { times }\end{array}$ & $\begin{array}{l}\text { Irrigation } 2 \\
\text { times \& } \\
\text { weeding } 2 \\
\text { times }\end{array}$ \\
\hline Longevity (days) & 103 & 110 & 80 & 102 & 50 & 80 & 80 \\
\hline $\begin{array}{l}\text { Turnaround period } \\
\text { (days) }\end{array}$ & 6 & 57 & 9 & 11 & 18 & 07 & 17 \\
\hline
\end{tabular}




\section{Rice Equivalent Yield}

The alternative cropping pattern's mean rice equivalent yield (REY) was $42.80 \mathrm{t} / \mathrm{ha} /$ year, which was $66 \%$ upper than the current patterns of cropping (25.76 t/ha/year). The REY of the alternative cropping style was $48.89 \mathrm{t} / \mathrm{ha} /$ year in the first cycle, which was $67 \%$ higher than the REY of the current cropping pattern (28.93 t/ha/year). While the REY of the alternative cropping style was $36.71 \mathrm{t} / \mathrm{ha} /$ year, it was $42.5 \%$ higher than the current cropping pattern $(25.76 \mathrm{t} / \mathrm{ha} /$ year $)$ in the second cycle. The alternative cropping pattern resulted in a greater rice equivalent yield due to the addition of agricultural technologies and varieties. As demonstrated by the preceding results, changing patterns of cropping resulted in upper yield when linked to the established pattern (Table 4). This argument was maintained by Rahman et al. [5], Nazrul et al. [16], Nazrul et al. [8], and Khan et al. [11] in the example of alternative crop sequence.

\section{E. Usage of Land}

Land efficiency is calculated by taking into account the amount of time that land is utilized throughout a cropping year. This is mostly determined by the duration of the crops. The changed cropping patterns yielded a better land efficiency $(86.16 \%)$ than the existing method (80.54\%). The alternative cropping patterns utilized $86.85 \%$ and $85.48 \%$ of the land, respectively, for the first and second cycles, whereas the existing pattern utilized $80.82 \%$ and $80.27 \%$ of the land, respectively, for the first and second cycles (Table IV). Due to the pattern's increased component crop cultivation, the alternate cropping pattern had a higher land-use efficiency. Rahman et al. [5] and Nazrul et al. [16] cited the findings' similar trend.

\section{F. Level of Productivity}

Maximum productivity was obtained by substituting an alternative cropping pattern for the current cropping pattern (Table IV). The integration of four crops, current technological varieties, and improved management practices may have contributed to greater efficiency of alternative cropping patterns. The alternative cropping pattern's mean production value was found to be $185.14 \mathrm{~kg} / \mathrm{ha} / \mathrm{day}, 45.20 \%$ greater than the current cropping pattern $(127.51 \mathrm{~kg} / \mathrm{ha} /$ day $)$. In the first cycle, cropping patterns produced 189.71 and $127.05 \mathrm{~kg} / \mathrm{ha} /$ day, including both, while cropping patterns produced 180.58 and $127.98 \mathrm{~kg} / \mathrm{ha} /$ day, respectively, in the second cycle (Table 4). Alternate cropping patterns produced $49 \%$ and $41 \%$ more than the current pattern in the first and second cycles, respectively.The analysis indicated that alternate cropping patterns against the current pattern were the most efficient cropping patterns in all cycles. In the case of alternative cropping patterns, Rahman et al. [5], Nazrul et al. [16] and Khan et al. [11] all cited similar findings.

\section{G. Creative Employment}

Labour was required to clear the land of obstructions, sow, and transplant crops, apply fertilizer, control weeds, spray pesticides, harvest, transport, thresh, dry, and clean the harvest. Compared to traditional cropping patterns, altered cropping patterns increase employment by $41 \%$ due to an increase in the number of man-days/ha/year requisite for crop growing (469 man-days/ha/year). Another benefit of including radish in the recipe is that it provides employment for women, children, and the elderly.

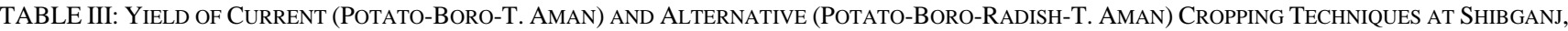
TABLE III: YIELD OF CURRENT (POTATO-BORO-T. AMAN) AND ALTERNATIVE (POT
BOGURA

\begin{tabular}{|c|c|c|c|c|c|c|c|}
\hline \multirow{2}{*}{$\frac{\text { Parameters }}{\text { Crop }}$} & \multicolumn{3}{|c|}{ Current Cropping Pattern } & \multicolumn{4}{|c|}{ Alternative Cropping Pattern } \\
\hline & Boro & T. aman & Potato & Boro & Radish & T. aman & Potato \\
\hline Variety & $\begin{array}{l}\text { BRRI dhan - } \\
28\end{array}$ & $\begin{array}{c}\text { BRRI dhan- } \\
49\end{array}$ & BARI Alu-8 & $\begin{array}{l}\text { BRRI dhan - } \\
28\end{array}$ & Rocky & $\begin{array}{l}\text { BRRI dhan- } \\
57\end{array}$ & BARI Alu-25 \\
\hline First cycle & & & & & & & \\
\hline $\begin{array}{c}\text { Grain/Tuber/Root Yield } \\
\text { (t/ha) }\end{array}$ & 5.56 & 5.12 & 26.80 & 5.44 & 24.90 & 3.7 & 26.10 \\
\hline $\begin{array}{l}\text { Straw yield (t/ha) } \\
\text { Second cycle }\end{array}$ & 6.31 & 6.09 & - & 6.12 & - & 4.30 & - \\
\hline $\begin{array}{c}\text { Grain/Tuber/Root Yield } \\
\text { (t/ha) }\end{array}$ & 5.59 & 5.10 & 26.81 & 5.46 & 20.29 & 4.19 & 26.40 \\
\hline $\begin{array}{c}\text { Straw yield (t/ha) } \\
\text { Average }\end{array}$ & 6.21 & 5.82 & - & 6.03 & - & 4.31 & - \\
\hline $\begin{array}{c}\text { Grain/Tuber/Root yield } \\
\text { (t/ha) }\end{array}$ & 5.57 & 5.11 & 26.80 & 5.45 & 22.59 & 3.94 & 26.25 \\
\hline Straw yield (t/ha) & 6.26 & 5.95 & - & 6.07 & - & 4.30 & - \\
\hline
\end{tabular}

TABLE IV: Rice EQuiVAlENT YiELD, LEVEl OF PRODUCTIVITY, USAGE OF LAND, AND ENGAGEMENT IN THE POPULATION OF THE CURRENT (PotATOBoro-T. AMAn) AND Alternative (Potato-Boro-RAdish-T. AmAn) PATTERns of CropPing AT SHIBGANJ, BOGURA

\begin{tabular}{|c|c|c|c|c|c|}
\hline Cycles & Patterns of cropping & $\begin{array}{l}\text { Rice equivalent } \\
\text { yield (t/ha) }\end{array}$ & Usage of land (\%) & $\begin{array}{l}\text { Level of Productivity } \\
(\mathrm{Kg} / \mathrm{ha} / \text { day })\end{array}$ & $\begin{array}{l}\text { Engagement in the population } \\
\text { (man- days/ha/year) }\end{array}$ \\
\hline \multirow[t]{4}{*}{$1^{\mathrm{st}}$} & Current & 28.93 & 80.82 & 127.05 & 472 \\
\hline & Alterative & 48.89 & 86.85 & 189.71 & 664 \\
\hline & & 6.74 & 2.18 & 13.05 & 38.4 \\
\hline & & $* *$ & $*$ & ** & $\begin{array}{ll}0.7 \\
* *\end{array}$ \\
\hline \multirow[t]{3}{*}{$2^{\text {nd }}$} & Current & 22.60 & 80.27 & 127.98 & 466 \\
\hline & Alterative & 36.71 & 85.48 & 180.58 & 656 \\
\hline & & $* *$ & $*$ & $* *$ & $* *$ \\
\hline \multirow[t]{4}{*}{ Mean } & Current & 25.76 & 80.54 & 127.51 & 469 \\
\hline & Alterative & 42.80 & 86.16 & 185.14 & 660 \\
\hline & & 5.34 & 4.89 & 21.89 & 63.20 \\
\hline & & $* *$ & $* *$ & $* *$ & $* *$ \\
\hline
\end{tabular}

* Indicates significance at $5 \%$ level of probability and ** Indicates significant at $1 \%$ level of probability. 


\section{H. Analysis of Profitability}

The estimated gross return on alterative and established cropping patterns was $842667 \mathrm{Tk}$./ha and $517077 \mathrm{Tk} . / \mathrm{ha}$, in both, according to the research (Table V). The estimated absolute return from alternative cropping patterns was $63 \%$ greater than the average gross return from current cropping patterns. The release of new crops and fast varieties may contribute to the increased gross return associated with alternate cropping patterns. The implied total variable cost of an alternative crop sequence and current cropping style were correspondingly $290281 \mathrm{Tk}$./ha and $239602 \mathrm{Tk}$./ha, including both (Table V). The alterative cropping pattern's overall average gross margin was $99 \%$ greater (552386 Tk./ha) than the current pattern's gross margin (277475 Tk./ha). It also included $22.59 \mathrm{t} / \mathrm{ha}$ of indicated yields in an alternative pattern of cropping due to the insertion of radish.

\section{Economic Benefit}

The average net economic benefits were $274911 \mathrm{Tk} . / \mathrm{ha} /$ year, implying that alterative cropping patterns based on four crops were more economically viable than current cropping patterns (Table VI). $282777 \mathrm{Tk}$./ha/year and $267046 \mathrm{Tk}$./ha/year showed a similar trend in the first and second cycles, respectively.

\section{CONCLUSION}

In this study, we evaluated the productivity level of a Potato-Boro-Radish-T. Aman rice cropping arrangement related to conventional crop production. After two cycles, the soil was also examined. The $\mathrm{pH}$ of the soil was somewhat higher than the starting value, but the organic content decreased due to the cropping pattern of four crops. The average crop length for alternative cropping patterns was 315 days, suggesting that four crop cropping patterns are economically sustainable as a replacement for current cropping patterns. In terms of mean REY, total grain/tuber yield was $42.80 \mathrm{t} / \mathrm{ha} /$ year, which was $66 \%$ higher than the previous pattern (25.76 t/ha/year). The overall average production efficiency $(185.14 \mathrm{~kg} / \mathrm{ha} /$ day $)$ of the alterative cropping pattern, land use efficiency $(86.16 \%)$, and labour employment (660 man-days/ha/year) of the alterative cropping pattern were $45 \%, 7 \%$, and $41 \%$ higher, respectively, then the current cropping pattern. Alternate farming patterns had a net economic benefit of 274911 Tk./ha/ year, suggesting that they were commercially feasible. The alternating cropping pattern also improved crop productivity, farmer knowledge, capacity, income, and employment. Farmers in the Bogura zone will benefit from better crop output per unit of ensuring food security. Additionally, it promotes soil health by incorporating Boro straw into soils with an alternate cropping pattern. Thus, it can be concluded that alternate cropping patterns benefit farmers in the Bogura region by providing a higher economic return. However, in this pattern, a strong marketing capability, particularly for radish, is critical.

\section{ACKNOWLEDGMENT}

The authors appreciate to the government of the People's Republic of Bangladesh, Ministry of Agriculture, Bangladesh Agricultural Research Institute (BARI), for their financial support for this research.

TABle V: Crop Control Techniques of the Current (Potato-Boro-T. Aman) And Alternative Cultivation Practices (Potato-BoroRADISH-T. AMAN) CROPPING STYLE IN THE FIRST AND SECOND CYCLES AT SHIBGANJ, BOGURA

\begin{tabular}{|c|c|c|c|c|}
\hline Cycles & Patterns of cropping & Absolute return (Tk./ ha) & Variable cost sum (Tk/ha) & Gross profit (Tk./ha) \\
\hline \multirow{2}{*}{ First } & Current & 507485 & 233210 & 274275 \\
\hline & Alternative & 843770 & 286718 & 557052 \\
\hline \multirow{2}{*}{ Second } & Current & 526670 & 245995 & 280675 \\
\hline & Alternative & 841565 & 293844 & 547721 \\
\hline \multirow{2}{*}{ Mean } & Current & 517077 & 239602 & 277475 \\
\hline & Alternative & 842667 & 290281 & 552386 \\
\hline
\end{tabular}

Market price of (first cycle) Potato @ 12 Tk.kg-1, Boro @ 15 Tk. kg-1, Straw @ 1.0 Tk.kg-1, T. Aman@ 17 Tk. kg-1, Straw @ 1.5 Tk.kg-1 Radish @ $15 \mathrm{Tkkg}^{-1}$.

Market price of (Second cycle) Potato @ 10 Tk.kg-1, Boro @ 22.5 Tk. kg-1, Straw @ 1.5 Tkkg-1, T. Aman@ 22.5 Tk. kg-1, Straw @ 1.5 Tk.kg-1Radish @ 17 Tk.kg-1.

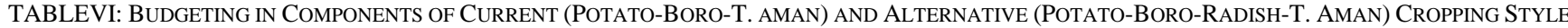
TABLEVI: BUDGETING IN COMPONENTS OF CURRENT (POTATO-BORO-T. AMAN) AND ALT
AT SHIBGANJ, BOGURA

\begin{tabular}{|c|c|c|c|c|}
\hline Cycles & Economic vulnerability & Tk./ha/year & Economic benifit & Tk./ha/year \\
\hline \multirow[t]{4}{*}{$1^{\text {st }}$} & $\begin{array}{l}\text { (a)Absolute return of current cropping } \\
\text { pattern }\end{array}$ & 507485 & $\begin{array}{l}\text { (e)Absolute return of alternative } \\
\text { cropping style }\end{array}$ & 843770 \\
\hline & $\begin{array}{l}\text { (b)Variable cost sum of alternative pattern } \\
\text { of cropping }\end{array}$ & 286718 & $\begin{array}{l}\text { (f)Variable cost sum of current } \\
\text { cropping style }\end{array}$ & 233210 \\
\hline & (c) Total $(a+b)$ & 794203 & $(g)$ Total $(e+f)$ & 1076980 \\
\hline & (d) The gross benefit (g-c) & 282777 & & \\
\hline \multirow[t]{4}{*}{$2^{\text {nd }}$} & $\begin{array}{l}\text { (a) Absolute return of current cropping } \\
\text { pattern }\end{array}$ & 526670 & $\begin{array}{l}\text { (e) Absolute return of alternative } \\
\text { cropping style }\end{array}$ & 841565 \\
\hline & $\begin{array}{l}\text { (b) Variable cost sum of alternative } \\
\text { patterns of cropping }\end{array}$ & 293844 & $\begin{array}{l}\text { (f) Variable cost sum of current } \\
\text { cropping style }\end{array}$ & 245995 \\
\hline & (c) Total $(a+b)$ & 820514 & (g)Total $(e+f)$ & 1087560 \\
\hline & (d) The gross benefit (g-c) & 267046 & & \\
\hline \multirow[t]{4}{*}{ Mean } & $\begin{array}{l}\text { (a) Absolute return of current cropping } \\
\text { pattern }\end{array}$ & 517077 & $\begin{array}{l}\text { (e) Absolute return of alternative } \\
\text { cropping style }\end{array}$ & 842667 \\
\hline & $\begin{array}{l}\text { (b) Variable cost sum of alternative } \\
\text { patterns of cropping }\end{array}$ & 290281 & $\begin{array}{l}\text { (f) Variable cost sum of current } \\
\text { cropping style }\end{array}$ & 239601 \\
\hline & (c) Total $(a+b)$ & 807358 & $(g)$ Total $(e+f)$ & 1082270 \\
\hline & (d) The gross benefit (g-c) & 274911 & & \\
\hline
\end{tabular}




\section{REFERENCES}

[1] BBS. Statistical year book of Bangladesh. Bangladesh Bureau of Statistics, Statistics Division, Ministry of Planning, Dhaka, Bangladesh, 2016.

[2] United Nations. United Nations, Department of Economic and Social Affairs, Population Division. World Population Prospects: The 2017 Revision. New York, 2017.

[3] Islam, M.F., and Haq, M.F. Integrated nutrient management with inorganic fertilizers and green manure in some dominant cropping patterns. In Proceedings of the national workshop on integrated nutrient management for crop production and soil fertility, ed. by M.F. Islam, D.A. Choudhury, G.M. Panaullah, M.U. Miah, J. Rijpma and M.F. Haque. Bangladesh Agricultural Research Institute: Gazipur, Bangladesh, 1999, pp. 55-72.

[4] Mondal, R. I., Begum, F., Aziz, A., and Sharif, S. H. Crop sequences for increasing cropping intensity and productivity. SAARC Journal of Agriculture, 2015;13(1):135-147.

[5] DAE. Department of Agriculture Extension, Paper presented in the regional research extension review and program planning workshop, RARS, Ishurdi, Pabna, 2015.

[6] Hossain, I., Mondal, M. R. I., Islam, M. J., Aziz, M. A., Khan, A. S. M. M. R., and Begum, F. Four crops based cropping pattern studies for increasing cropping intensity and productivity in Rajshahi region of Bangladesh. Bangladesh Agronomy Journal, 2014;17(2): 55-60.

[7] Rahman, M.S., Islam, M.T., Prodhan, M.Z.H., Hasan, M.K., and Khan, A.S.M.M.R. Productivity and Profitability of improved versus existing cropping pattern in Kushtia region. Bangladesh Journal of Agricultural Research, 2018;43(4): 587-598.

[8] Nazrul, M. I., Shaheb, M. R., Khan, M. A. H., and Khan, S. M. M. R.A. On-farm evaluation of production potential and economic returns of Potato-Rice Based improved cropping system. Bangladesh Journal of Agricultural Research, 2013;16(2): 41-50.

[9] Azad, A. K., Talukdar, F. A. H., Wahhab M. A., and Khan, M. A. Progress and prospect of jute based cropping systems research in Bangladesh. Proc. Expert Cons. Jute and Kenaf Improvement, 1982, pp. 244-267.

[10] Kamrozzaman, M. M., Khan, M. A. H., Ahmed, S., and Ruhul Quddus, A. F. M. On- farm evaluation of production potential and economics of Wheat-Jute-T. Aman rice- based cropping system. Journal of Bangladesh Agricultural University, 2015;13(1): 93-100.

[11] Khan, M. A. H., Quayyum, M. A., Nazrul, M. I., Sultana, N., and Mollah, M.R.A. On-farm evaluation of production potential and economics of mustard-rice based improved cropping system. J. Socio. Res. Dev., 2005;2(1): 37-42.

[12] Malavia, D. D., Singh, M. P., Vyas, M. M., Patel, J. C., and Kalaria. K. K. Production potential and economic feasibility of different crop sequences. Indian Journal of Argonomy, 1986;31(1): 75-78.

[13] Soni, P. N., and Kaur, R. Studies on production potential of different cropping systems. Indian Journal of Agronomy, 1984;29(3): 367-78.

[14] Tomer, S. S., and Tiwari, A. S. Production potential and economics of different crop sequences. Indian Journal of Agronomy, 1990;35(1, 2): 30-35.

[15] Verma, S. P., and Modgal, S. C. Production potential and economics of fertilizer application as resources constraints in maize, wheat crop sequence. Himachal J.Agric. Res. 1983;9(2): 89-92.

[16] Nazrul, M. I., Hasan, M. K., and Mondal, M. R. I. Production potential and economics of mungbean in rice based cropping pattern in Sylhet region under AEZ 20. Bangladesh J. Agril. Res. 2017;42(3): 413-424.

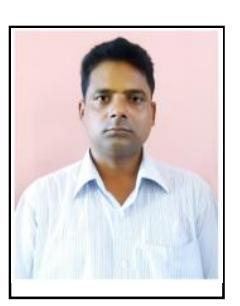

Md. Tanbir Hasan was born on 26 March 1978 at Uthabi, Gobindoganj under Gaibandha district of Rangpur division in Bangladesh. He is currently employed as a Scientific Officer in the Bangladesh Agricultural Research Institute's On-Farm Research Division in Bogura, Bangladesh. Mr. Tanbir earned a BSc.Ag (Honours) in Agriculture and a Master of Science (MS) in Soil Science from Bangladesh Agricultural University in Mymensingh, Bangladesh, in 2003 and 2005, respectively.

Mr. Tanbir's initial research focused on cropping pattern development, soil fertility management, crop management practices, soil health improvement, carbon and nitrogen mineralization, and fallow land utilization practices in order to better understand the effects of cropping intensity and crop production in Bangladesh. He has worked on four crop based cropping pattern, yield gap, Bt brinjal variety trial and intercropping different crops at
Bogura region in Bangladesh. This work has been published in twelve national and international journals. He was awarded a National Agricultural Training Programme (NATP) Fellowship by the Ministry of Agriculture, Government of Bangladesh, to conduct $\mathrm{PhD}$ research between 2019 and 2021. His research focusses on "Mineralization and Nutrient Dynamics of Different Organic Materials in Industrial Polluted Soil". He is a life member of Krishibid Institution of Bangladesh, Bangladesh Agricultural Research Institute Scientists Association and Soil Science Society of Bangladesh. 